\title{
The Inhibition Action of Essential Oil of J. Juniperus Phoenicea on the Corrosion of Mild Steel in Acidic Media
}

\author{
Y. Elkhotfi ${ }^{a, *}$, I. Forsal $^{a}$, E.M. Rakib ${ }^{a}$ and B. Mernari ${ }^{b}$ \\ ${ }^{a}$ Organic and Analytical Chemistry Laboratory, University Sultan Moulay Slimane, \\ Faculty of Sciences and Technologies, Beni Mellal, Morocco \\ ${ }^{b}$ Coordination and Analytical Chemistry Laboratory, Chouaib Doukkali University, \\ Faculty of Sciences El Jadida, Morocco
}

Received December 28, 2016; accepted July 1, 2017

\begin{abstract}
Essential oil of Juniperus phoenicea (Cupressaceae) is extracted from the natural plant collected in Morocco. Extracted by distillation, its inhibiting action on the corrosion of mild steel in $1 \mathrm{M}$ acidic media has been investigated by weight loss and various electrochemical techniques. Obtained results reveal that this naturally occurring substance is a very good inhibitor. The inhibition efficiency was found to increase with the oil content, attaining $83 \%$ at $1500 \mathrm{ppm}$. The oil of Juniperus phoenicea acts as a mixed-type inhibitor. The adsorption isotherm and the thermodynamic data of adsorption and activation are herein determined and discussed.
\end{abstract}

Keywords: Steel, acid solution, weight loss, acid corrosion, adsorption.

\section{Introduction}

Environmental technology, also called green or clean technology, is the application of environmental science to conserve the natural environment and resources, and to curb the negative impacts of human involvement. Sustainable development is the core of environmental technologies. Owing to increasing ecological awareness, strict environmental regulations and the need of environmentally friendly processes, research is now focused on the development of substitute nontoxic biodegradable natural-compounds [1].

In this frame, most of the naturally occurring substances are safe and can be extracted by simple and cheap procedures. Recent literature is full of researches which test different extracts for corrosion inhibition applications [2-12].

Many oils extracted from different parts of different plants are rich in aroma compounds. Many of these naturally occurring substances proved their ability to act as inhibitors for the corrosion of different metals and alloys in different aggressive media. To value the inhibitory performance of the essential oil

\footnotetext{
* Corresponding author. E-mail address: elkhotfi@gmail.com
} 
of Juniperus phoenicea, weight loss and electrochemical techniques (AC impedance and polarization techniques) have been employed. The effect of concentration and temperature on the inhibition efficiency has been examined. The thermodynamic parameters for both dissolution and adsorption processes were calculated and discussed.

\section{Materials and methods}

\section{Natural oil of Juniperus phoenicea}

The essential oil of Juniperus phoenicea, endemic to Morocco, was isolated by distillation, and analyzed by gas chromatography-mass spectrometry (GC-MS) [13].

\section{Specimens}

Mild steel specimens containing $0.09 \% \mathrm{P}, 0.38 \% \mathrm{Si}, 0.01 \mathrm{Al}, 0.05 \% \mathrm{Mn}, 0.21 \%$ $\mathrm{C}, 0.05 \% \mathrm{~S}$ and the remainder $\mathrm{Fe}$, were used for gravimetric and electrochemical measurements. These steel specimens were mechanically cut into $1 \mathrm{~cm} \times 5 \mathrm{~cm} \times$ $0.06 \mathrm{~cm}$ dimensions for weight loss and electrochemical experiments. Prior to all measurements, they were mechanically polished on wet $\mathrm{SiC}$ paper (grade 400 800 - 1200), rinsed with double distilled water, ultrasonically degreased in ethanol for $5 \mathrm{~min}$, and dried at room temperature.

\section{Electrolytes}

Aggressive solutions of $1 \mathrm{M} \mathrm{HCl}$ were prepared by dilution of analytical grade $37 \%$ with double distilled water. The concentration range of the employed inhibitors has varied from $800 \mathrm{ppm}$ to $1500 \mathrm{ppm}$ in $1 \mathrm{M} \mathrm{HCl}$, and the used electrolyte was $50 \mathrm{~mL}$.

\section{Methods}

Gravimetric measurement

The weight loss of steel, with and without the addition of different oil concentrations, was determined after immersion in acid over $24 \mathrm{~h}$ at $30^{\circ} \mathrm{C}$, and the percentage inhibition efficiency $(\eta \%)$ was calculated from:

$$
\eta \%=\frac{w_{0}-w}{w_{0}}
$$

where $\boldsymbol{w}_{0}$ and $\boldsymbol{w}$ are the values of the corrosion weight loss of steel after immersion in solutions, respectively, without and with inhibitor.

\section{Electrochemical measurement}

Electrochemical experiments were conducted using impedance equipment (Tacussel-Voltalab PGZ 100), and controlled with Tacussel corrosion analysis software model Voltamaster 4.

A conventional three electrode glass cell assembly with a mild steel rod was used as working electrode (we); a platinum foil of $3-3 \mathrm{~cm}$ as auxiliary electrode; and 
(CE) $\mathrm{Hg} / \mathrm{Hg}_{2} \mathrm{Cl}_{2} / \mathrm{KCl}$ saturated (SCE) for the $1 \mathrm{M} \mathrm{HCl}$ medium, were used as reference electrodes. AC impedance measurements were carried-out at $\mathbf{E}_{\text {Corr }}$ after immersion in a solution without bubbling, and the rectangle surface of the steel, with $1 \mathrm{~cm}^{2}$ exposed to the solution, was used as working electrode. After the determination of steady state current at a given potential, peak to peak sine wave voltage $(10 \mathrm{mV})$, at frequencies between $100 \mathrm{KHz}$ and $10 \mathrm{mHz}$, was superimposed on the open circuit potential. Computer programs automatically controlled the measurements performed at rest potentials after $30 \mathrm{~min}$ of exposure. The impedance diagrams are given in the Nyquist representation. Values of $\mathbf{R}_{\mathbf{t c}}$ and $\mathbf{C}_{\mathbf{d l}}$ were obtained from Nyquist plots. For polarization curves, potentiodynamic polarisation studies were performed with a scan rate of $1 \mathrm{mV} . \mathrm{s}^{-1}$ in the potential range from $-750 \mathrm{mV}$ to $-100 \mathrm{mV}$, relative to the corrosion potential.

\section{Results and discussion \\ Weight loss measurements}

The inhibitor efficiency increased with the oil content. The inhibition was estimated to be superior to $78 \%$ in $1 \mathrm{M} \mathrm{HCl}$, even at different concentrations, and the optimum concentration for maximum efficiency was found to be 1500 ppm of oil.

The inhibition efficiencies calculated from the weight loss measurements for different amounts of essential oil of Juniperus phoenicea in $1 \mathrm{M} \mathrm{HCl}$ are summarized in Table 1.

Table 1. Dependence of mild steel corrosion inhibition efficiency of essential oil of Juniperus phoenicea on its concentration in $1 \mathrm{M} \mathrm{HCl}$ at $25^{\circ} \mathrm{C}$, exposed for $24 \mathrm{~h}$.

\begin{tabular}{|c|c|}
\hline Concentration $(\mathrm{ppm})$ & Inhibition efficiency $(\%)$ \\
\hline Blanc & - \\
\hline 800 & 79 \\
\hline 1200 & 81 \\
\hline 1500 & 83 \\
\hline
\end{tabular}

\section{Polarization measurements}

The polarization curves of steel in $1 \mathrm{M} \mathrm{HCl}$, in the absence and presence of the essential oil at $25{ }^{\circ} \mathrm{C}$, are presented in Fig. 1.The collected parameters deduced from the polarization curves, such as corrosion potential $\left(\mathbf{E}_{\text {Corr }}\right)$, corrosion current $\left(\mathbf{I}_{\text {Corr }}\right)$, Tafel slopes $\left(\mathbf{b}_{\mathfrak{c}}\right),\left(\mathbf{b}_{\mathbf{a}}\right)$, and percentage inhibition efficiency, are shown in Table 2.

Examination of Fig. 1 and Table 2 shows that. The cathodic current density decreases with the natural substance concentration. The slopes of cathodic Tafel lines, $\mathbf{b}_{\boldsymbol{c}}$, and the corrosion potential remain almost constant upon the addition of the inhibitor concentration. This result indicates that the reduction mechanism of the hydrogen ion is modified in the oil's presence [14-15]. In the anodic range, the polarization curves in steel in $1 \mathrm{M} \mathrm{HCl}$, with and without oil, show that the inhibitor presence decreases the current density. This fact means that the 
essential oil of Juniperus phoenicea inhibits anodic reaction and acts a mixedtype inhibitor.

The inhibition efficiency increases with the inhibitor concentration, attaining $83 \%$ at $1500 \mathrm{ppm}$ of the natural substance.

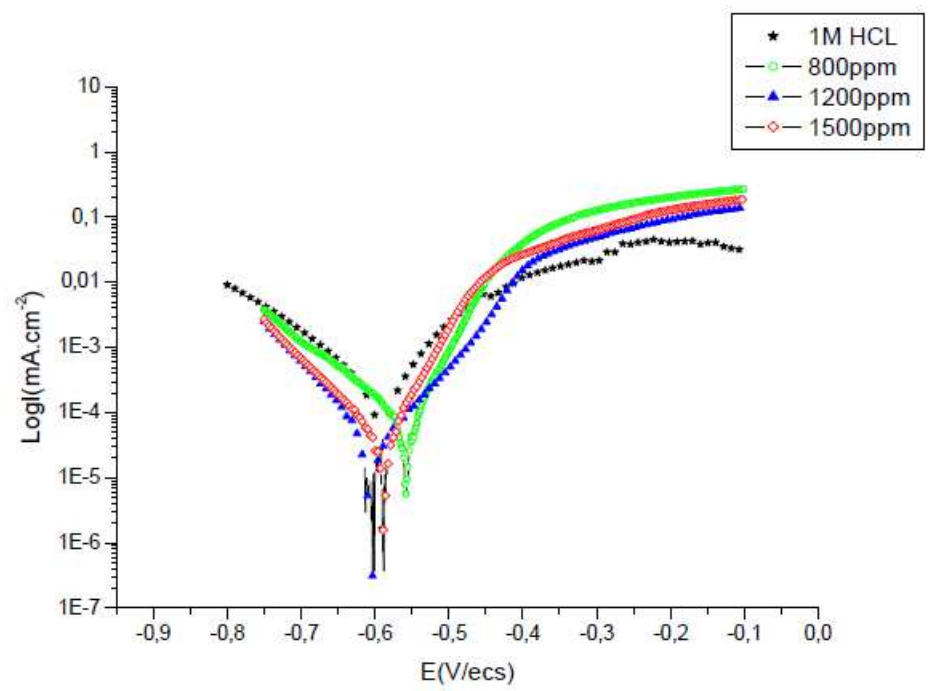

Figure 1. Polarization curves of steel in $1 \mathrm{M} \mathrm{HCl}$ containing various concentrations of inhibitor.

Table 2. Electrochemical parameters of steel at various concentrations of oil in $1 \mathrm{M}$ $\mathrm{HCl}$, and corresponding inhibition efficiencies.

\begin{tabular}{|c|c|c|c|c|c|}
\hline Conc. $(\mathrm{ppm})$ & $\mathbf{I}_{\text {Corr }}\left(\mu \mathrm{A} / \mathrm{cm}^{2}\right)$ & $\mathbf{E}_{\text {Corr }}(\mathrm{mV})$ & $\mathbf{b}_{\mathbf{z}}(\mathrm{mV})$ & $\mathbf{b}_{\mathfrak{c}}(\mathrm{mV})$ & Efficiency \\
\hline blanc & 362 & -593 & 109.7 & -149.4 & - \\
\hline 800 & 72 & -560 & 46.6 & -102.7 & 80.1 \\
\hline 1200 & 70 & -607 & 97.1 & -84.3 & 80.6 \\
\hline 1500 & 59 & -589 & 52 & -88 & 83.7 \\
\hline
\end{tabular}

\section{Electrochemical impedance spectroscopy (EIS)}

The corrosion of mild steel in an acidic solution, in the presence of a natural substance, was investigated by EIS. Nyquist plots of steel, in inhibited and uninhibited acidic solutions containing various concentrations of oil, are shown in Fig. 2. The obtained impedance diagrams are not perfect semicircles, and this difference has been attributed to frequency dispersion [16-18].

The transfer resistance values $\left(\mathbf{R}_{\mathrm{tc}}\right)$ are calculated from the difference in impedance at lower and higher frequencies [19]. To obtain the double layer capacitance $\left(\mathbf{C}_{\mathrm{dll}}\right)$, the frequency at wich the imaginary component of the impedance $\left(-\mathbf{Z}_{\max }\right)$ is found, and $\mathbf{C}_{\mathrm{dl}}$ values, are obtained from the equation:

$$
f\left(-Z_{\max }\right)=\frac{1}{2 \pi R_{t s} C_{d l}}
$$

The inhibition efficiency is calculated by transfer resistance, as follows: 


$$
\eta \%=\frac{\mathbf{R}_{\mathrm{tc}}-\mathbf{R}_{\mathrm{tc0}}}{\mathbf{R}_{\mathrm{tc0}}}
$$

where $\mathbf{R}_{\mathbf{t c}}$ and $\mathbf{R}_{\mathbf{t c 0} 0}$ are the transfer resistances for mild steel in $1 \mathrm{M} \mathrm{HCl}$, respectively, with and without inhibitor.

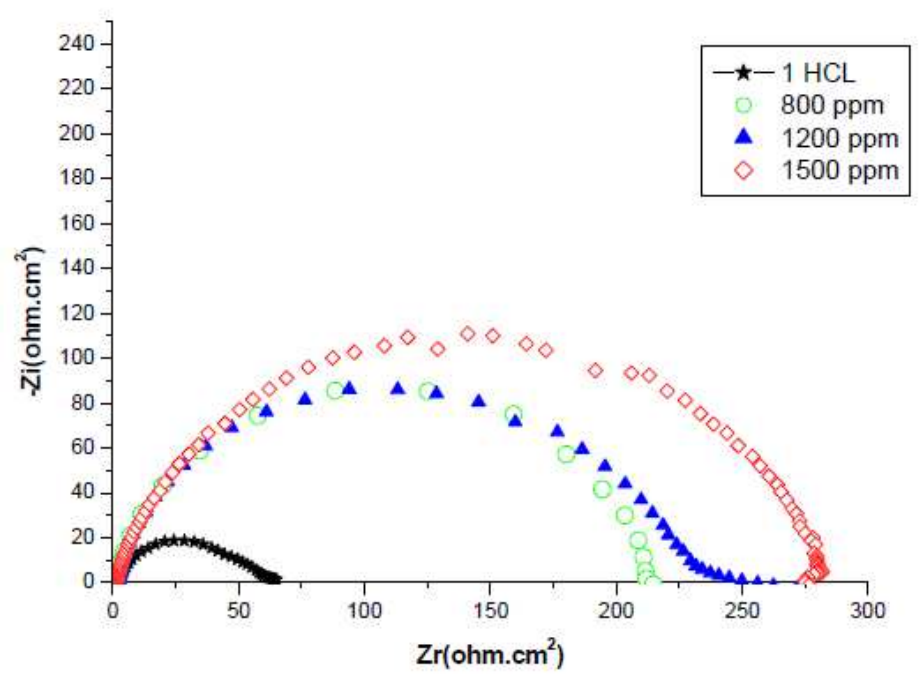

Figure 2. Nyquist diagrams for mild steel in $1 \mathrm{M} \mathrm{HCl}$ containing different concentrations of oil.

It is found (Table 3) that, as the oil concentration increases, the $\mathbf{R}_{\mathbf{t c}}$ values increase (Fig. 3), but the $\mathbf{C}_{\mathrm{dl}}$ values tend to decrease (Fig. 4). The decrease in $\mathbf{C}_{\mathrm{dl}}$ values is due to the adsorption of aroma compounds onto the metal surface [20]. The electrochemical study confirms the results of the weight loss measurements. The Juniperus phoenicea's oil appears to be a good inhibitor in $1 \mathrm{M} \mathrm{HCl}$, with a maximum efficiency of $83 \%$.

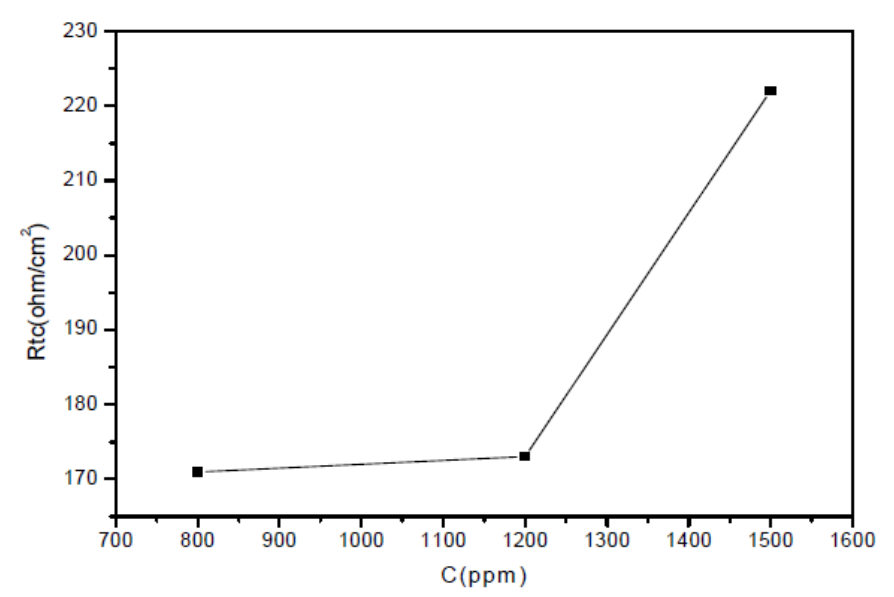

Figure 3. Change of $\mathbf{R}_{\mathrm{tc}}$ with additive concentrations. 
Table 3. Characteristic parameters evaluated from the impedance diagram for steel in 1 $\mathrm{M} \mathrm{HCl}$, at various oil concentrations.

\begin{tabular}{|c|c|c|c|c|c|}
\hline Conc. (ppm) & $\mathbf{R}_{\text {tc }}$ & $\mathrm{f}(\mathrm{Hz})$ & $\mathbf{C}_{\mathrm{dl}}\left(\mu \mathrm{F} / \mathrm{cm}^{2}\right)$ & $\mathbf{R}_{\mathbf{P}}$ & Efficiency \\
\hline blanc & 37 & 6.32 & 120.42 & 61 & - \\
\hline 800 & 171 & 10 & 115.4 & 215 & 78.36 \\
\hline 1200 & 173 & 10.1 & 111.9 & 238 & 78.61 \\
\hline 1500 & 222 & 7.93 & 72.71 & 284 & 83.33 \\
\hline
\end{tabular}

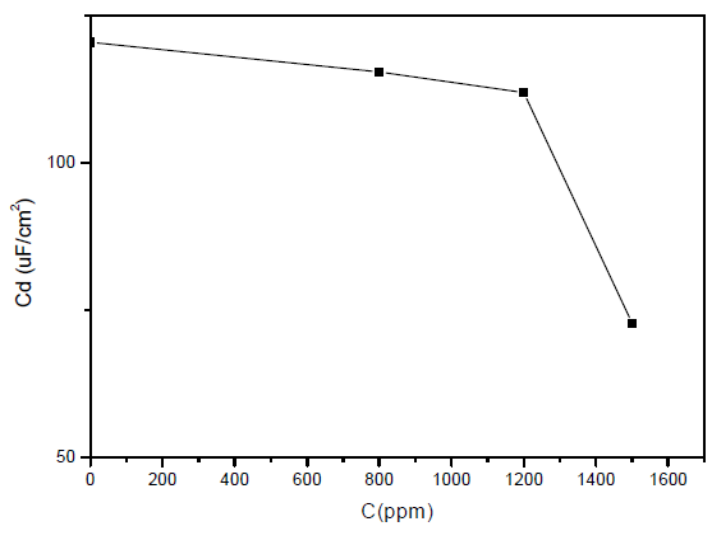

Figure 4. Change of double layer capacitance with additive concentrations.

\section{Effect of temperature}

The effect of temperature on the anti-corrosion effectiveness of oil, studied at various concentrations in the temperature domain of 298-333 K, at $2 \mathrm{~h}$ of immersion, is summarized in Table 4.

Table 4. Inhibition efficiencies obtained from the corrosion rate for different oil concentrations at different temperatures, exposed for $2 \mathrm{~h}$.

\begin{tabular}{|c|c|c|c|c|}
\hline Temperature $(\mathrm{K})$ & Concentration $(\mathrm{M})$ & $\mathrm{W}\left(\mathrm{mg} / \mathrm{cm}^{2} . \mathrm{h}\right)$ & $\mathbf{E}_{\mathbf{W}} \%$ & $\theta$ \\
\hline \multirow{3}{*}{298} & Blanc & 2.3 & - & - \\
\cline { 2 - 5 } & 800 & 0.472 & 79 & 0.79 \\
\cline { 2 - 5 } & 1200 & 0.437 & 81 & 0.81 \\
\cline { 2 - 5 } & 1500 & 0.391 & 83 & 0.83 \\
\hline \multirow{3}{*}{303} & Blanc & 3.317 & - & - \\
\cline { 2 - 5 } & 800 & 0.762 & 77 & 0.77 \\
\cline { 2 - 5 } & 1200 & 0.729 & 78 & 0.78 \\
\cline { 2 - 5 } & 1500 & 0.663 & 80 & 0.80 \\
\hline \multirow{3}{*}{313} & Blanc & 4.463 & - & - \\
\cline { 2 - 5 } & 800 & 1.383 & 69 & 0.69 \\
\cline { 2 - 5 } & 1200 & 1.249 & 72 & 0.72 \\
\hline \multirow{3}{*}{323} & 1500 & 1.026 & 77 & 0.77 \\
\hline & Blanc & 5.430 & - & - \\
\cline { 2 - 5 } & 800 & 2.606 & 52 & 0.52 \\
\cline { 2 - 5 } & 1200 & 2.280 & 58 & 0.58 \\
\hline \multirow{3}{*}{333} & 1500 & 2.063 & 62 & 0.62 \\
\hline & Blanc & 8.556 & - & - \\
\cline { 2 - 5 } & 800 & 5.475 & 36 & 0.36 \\
\cline { 2 - 5 } & 1200 & 4.435 & 47 & 0.47 \\
\cline { 2 - 5 } & 1500 & 4.278 & 50 & 0.50 \\
\hline
\end{tabular}


The collected curves in Fig. 5 show the evolution of the corrosion rate (W) with oil concentration $(\mathrm{C})$, at different temperatures.

Fig. 5 indicates that, at a given oil concentration, the corrosion rate of steel increased with temperature. The increase is more pronounced at weak concentrations. The results also indicate that, for a given temperature, the corrosion rate of steel decreased with increasing inhibitor concentration. The values of inhibition efficiency obtained from weight loss for different inhibitor concentrations, and at various temperatures, in $1 \mathrm{M} \mathrm{HCl}$, are given in Table 4 and Fig 5. The results show that the inhibition efficiency decreases with increasing temperature, indicating that the dissolution of steel at higher temperatures predominates on the adsorption of aroma compounds onto the surface.

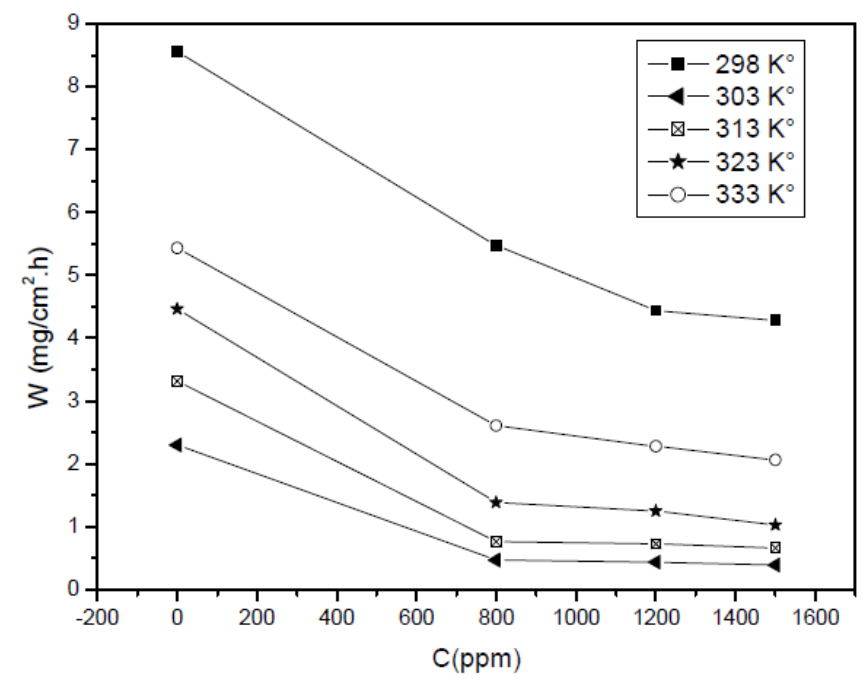

Figure 5. Relationship between corrosion rate and inhibitor concentration.

\section{Thermodynamic parameters}

The activation kinetic parameters, such as energy $\left(\mathbf{E}_{\mathbf{a}}\right)$, enthalpy $\left(\Delta \mathbf{H}_{\mathbf{a}}^{a}\right)$ and entropy $\left(\Delta \mathbf{S}_{\mathrm{a}}^{\mathrm{a}}\right)$, may be evaluated from the effect of temperature on the inhibitor, using Arrhenius law (Eq. 4) and the alternative formulation of Arrhenius equation (Eq. 5) [21].

$$
\begin{aligned}
& I=\operatorname{Aexp}\left(-\frac{E_{2}}{\mathrm{RT}}\right) \\
& I=\frac{\mathrm{RT}}{\mathrm{Nh}} \exp \left(-\frac{\Delta S_{2}^{\mathrm{Z}}}{\mathrm{R}}\right) \exp \left(-\frac{\Delta \mathrm{H}_{2}^{\mathrm{T}}}{\mathrm{RT}}\right)
\end{aligned}
$$

where $\mathrm{A}$ is the Arrhenius pre-exponential factor, $\mathrm{T}$ the absolute temperature, $\mathbf{E}_{\mathrm{a}}$ the activation corrosion energy for the corrosion process, $\mathrm{h}$ the Planck's constant, $\mathrm{N}$ the Avogadro's number, $\Delta \mathbf{S}_{\mathrm{a}}^{\circ}$ the entropy of activation, $\Delta \mathbf{H}_{\mathrm{a}}^{\circ}$ the enthalpy of activation, and $\mathrm{I}$ is the corrosion rate of steel.

The apparent activation energies $\left(\mathbf{E}_{\mathbf{a}}\right)$ and pre-exponential factors (A) are calculated by linear regression between $\mathbf{I n ( I )}$ and 1/T (Fig. 6). 


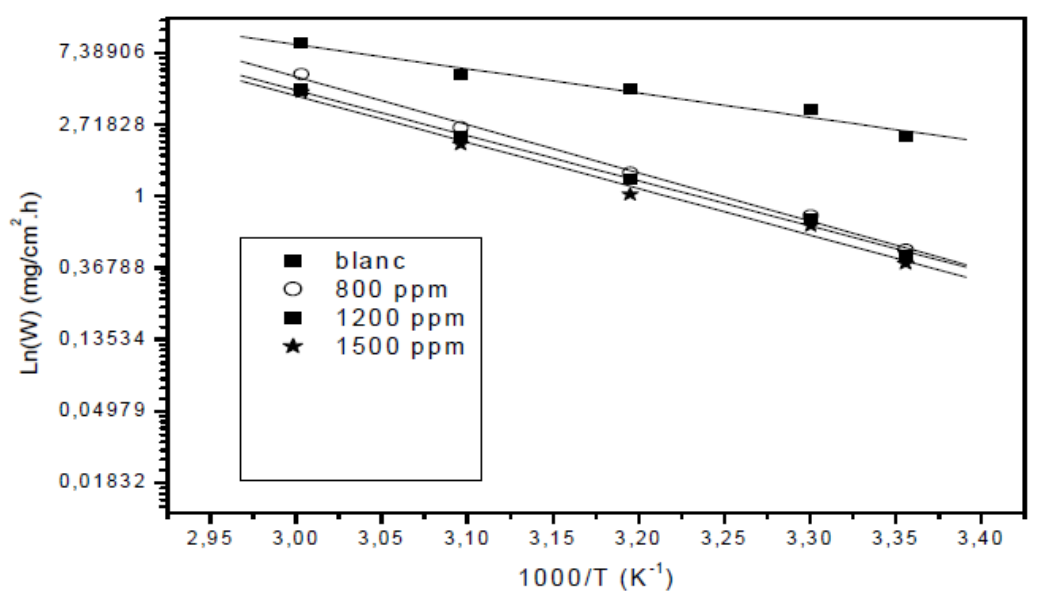

Figure 6. Arrhenius plots of steel for various concentrations of Juniperus phoenicea oil in $1 \mathrm{M} \mathrm{HCl}$.

The apparent activation corrosion energies in the absence and presence of 1500 ppm of Juniperus phoenicea oil were found to be, respectively, 28.17 and 52.52 $\mathrm{kJ} / \mathrm{mol}$. The pre-exponential factors (A) and $\mathbf{E}_{\mathbf{a}}$ show the same trend. The increase in $\mathbf{E}_{\mathbf{a}}$, in the oil presence, may be interpreted as the likely specific interaction between the iron surface and aroma compounds [22], that occurs in the first stage [23]. The increase in activation energy can be attributed to an appreciable decrease in the adsorption of the aroma compounds onto the mild steel surface with an increase in temperature. A corresponding increase in the corrosion rate occurs because of the greater area of metal that is consequently exposed to the acid environment.

Fig. 7 shows plots of $\ln \left(\frac{w}{T}\right)$ against $1 / T$. Straight lines are obtained with a slope of $\left(-\Delta \mathbf{H}_{\mathrm{a}}^{\circ} / \mathrm{R}\right)$ and an intercept of (ln $\left.\mathrm{R} / \mathrm{Nh}+\Delta \mathbf{S}_{\mathrm{a}}^{\circ} / \mathrm{R}\right)$, from which the values of $\Delta \mathbf{H}_{\mathrm{a}}^{\mathrm{s}}$ and $\Delta \mathbf{S}_{\mathrm{a}}^{\mathrm{s}}$ are calculated (Table 5).

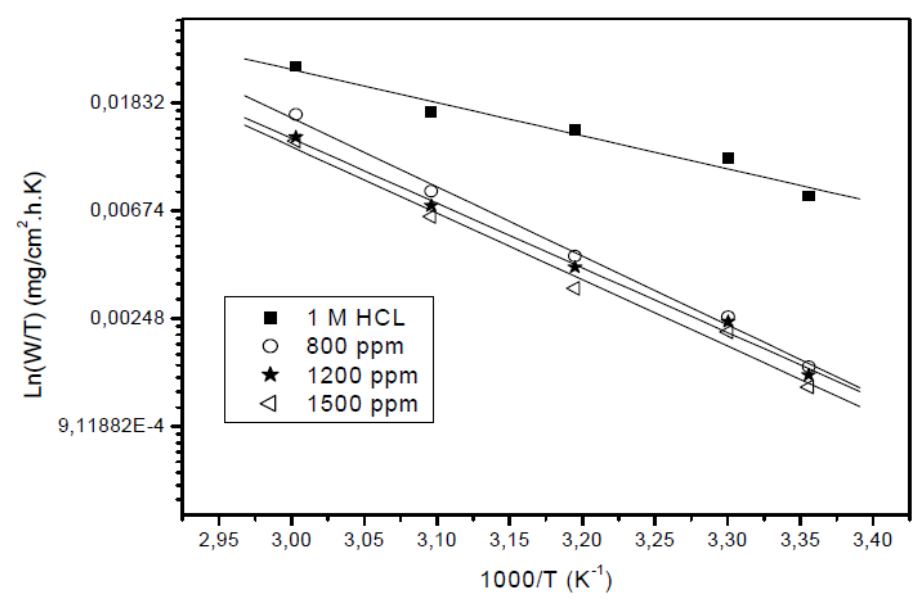

Figure 7. Plots of $\ln (\mathrm{W} / \mathrm{T})$ against $\mathrm{T}^{-1}$ for various concentrations of oil in $1 \mathrm{M}$ of $\mathrm{HCl}$.

The obtained values of $\Delta \mathbf{H}_{\mathrm{a}}^{\alpha}$ are $25.55,51.27,53.28$ and $52.52 \mathrm{Kj} / \mathrm{mol}$ for free acid and 800, 1200 and $1500 \mathrm{ppm}$ in acid added with oil, respectively. The positive signs of the enthalpies, $\Delta \mathbf{H}_{\mathrm{a}}^{\mathrm{a}}$, reflect the endothermic nature of the steel dissolution process, and mean that the dissolution of steel is difficult [24]. 
Table 5. Thermodynamic parameters for the adsorption of oil onto the mild steel in $1 \mathrm{M}$ HCl.

\begin{tabular}{|c|c|c|c|c|}
\hline Concentration $(\mathrm{ppm})$ & $\mathrm{K}\left(\mathrm{mg} / \mathrm{cm}^{2} . \mathrm{h}\right)$ & $\mathbf{E}_{\mathbf{2}}(\mathrm{kj} / \mathrm{mol})$ & $\Delta \mathrm{H}_{\mathbf{2}}^{\mathbf{z}}(\mathrm{kj} / \mathrm{mol})$ & $\Delta \mathbf{S}_{\mathbf{2}}^{\mathbf{z}}(\mathrm{j} / \mathrm{mol} . \mathrm{K})$ \\
\hline- & $2.13209 .10^{5}$ & 28.17 & 25.55 & -84.76 \\
\hline 800 & $2.99437 .10^{9}$ & 55.89 & 51.27 & 27.57 \\
\hline 1200 & $1.11264 .10^{9}$ & 53.89 & 53.28 & 31.10 \\
\hline 1500 & $1.86056 .10^{8}$ & 52.52 & 52.52 & 39.32 \\
\hline
\end{tabular}

The positive values of entropies $\left(\Delta \mathbf{S}_{\mathrm{a}}^{a}\right)$ in the inhibitor presence imply that the activated complex in the rate determining step represents an association rather than a dissociation step, meaning that an increase in disordering takes place on going from the reactants to the activated complex [25].

\section{Adsorption isotherm}

The surface coverage, $\theta$, was calculated according to the following equation:

$$
\theta=\frac{w_{0}-w}{w_{0}}
$$

Surface coverage values $(\theta)$ for the inhibitor were obtained from the weight loss measurements for various concentrations at different temperatures (303-333 K), as shown in Table 4.

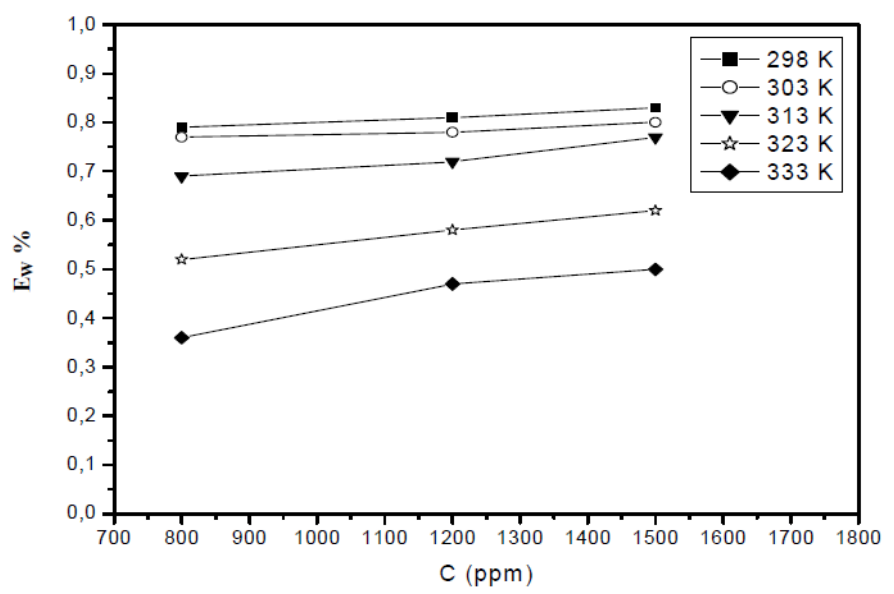

Figure 8. Relationship between inhibition efficiency, $\mathrm{E}_{\mathrm{W}} \%$, and oil concentration in 1 $\mathrm{M} \mathrm{HCl}$.

The dependence of the fraction of the covered surface, $\theta$, obtained by the ratio $\mathbf{E}_{W} / 100$, on the concentration (C) (Fig. 8), was graphically fitted for Langmuir, Temkin, Frumkin and Freundlich adsorption isotherms. The models considered were [26].

Temkin isotherm

$$
\exp (\mathbf{f} . \theta)=K_{\mathrm{ads}} \mathbf{C}
$$

Langmuir isotherm

$$
\theta /(1-\theta)=\mathbf{K}_{\mathrm{ads}^{*}} \boldsymbol{C}
$$

Frumkin isotherm

$$
\frac{\theta}{(1-\theta)} \cdot \exp (-2 \mathrm{f} \cdot \theta)=K_{\mathrm{ads}} \cdot \mathrm{C}
$$


and Freundlich isotherm

$$
\theta=K_{a d s}, C
$$

where $\mathbf{K}_{\text {ads }}$ is the equilibrium constant of the adsorption process, $\mathrm{C}$ the inhibitor concentration and $f$ the factor of energetic inhomogeneity [27].

The modes of adsorption mainly depend on the chemical structure of the active molecules of this oil. The adsorption mainly depends on the electronic and structural properties of aroma compounds, such as functional groups, steric factors, aromaticity, and electron density [28-29].

\section{Conclusion}

1. The essential oil of Juniperus phoenicea acts as a good inhibitor for the corrosion of steel in acidic media.

2. Essential oil of Juniperus phoenicea acts as a mixed-type inhibitor.

3. The inhibition efficiency of oil decreases with the rise in temperature within the range $298-333 \mathrm{~K}$.

4. The results obtained from weight loss, potentiodynamic polarization and impedance spectroscopy are in good agreement.

\section{Acknowledgments}

The authors are pleased to acknowledge Laboratory Electrochemistry and Corrosion Studies, Faculty of Science Kenitra, for technical assistance.

\section{References}

1. Oguzie EE, Li Y, Wang FH. J Colloid Interface Sci. 2007;310:90.

2. El-Etre AY, Abdallah M, El-Tantawy ZE. Corros Sci. 2005;47:385.

3. El-Etre AY. Corros Sci. 2003;45:2485.

4. Avwiri GO, Igho FO. Mater Let. 2001;57:3705.

5. El-Etre AY, Abdallah M. Corros Sci. 2000;42:731.

6. Martinez S, Stern I. Appl Surf Sci. 2002;199:83.

7. El-Etre AY, Abdallah M. Corros Sci. 2000;42:731.

8. Chetouani A, Hammouti B. Bull Electrochem. 2003;19:23.

9. Chetouani A, Hammouti B. Bull Electrochem. 2004;20.

10. Benabdellah M, Benkaddour M, Hammouti B, et al. 2006;52:6212.

11. Znini M, Bouklah M, Majidi L, et al. Int J Electrochem Sci. 2011;6:691.

12. Chaieb EL, Bouyanzer A, Hammouti B, et al. Appl Surf Sci. 2005;249:183.

13. Achak N, Romane A, Abbad A, et al. J Ess Oi Bear Plan. 2008;11:137.

14. Lagreneé M, Mernari B, Chaibi N, et al. Corros Sci. 2001;43:951.

15. Bentiss F, Traisnel M, Vezin H, et al. Corros Sci. 2003;45:371.

16. Mansfeld F, Kending MW, Tsai S. Corrosion. 1981;37:301.

17. Hsu CH, Mansfeld F. Corrosion. 2001;57:747.

18. Bentiss F, Bouanis M, Mernari B, et al. Corrosion. 2007;273:3696.

19. Tsuru T, Haruyama S, Gijutsu B. J Japan Soc Corros Eng. 1978;27:573. 
20. Bentiss F, Lebrini M, Lagrenée M. Corros Sci. 2005;47:2915.

21. Arab ST, Noor EA. Corrosion. 1993;49:122.

22. Popova A, Sokolova E, Raicheva S, et al. Corros Sci. 2003;45:33.

23. El Sherbini EF. Mater Chem Phys. 1999;60:286.

24. Gomma MK, Wahdan MH. Mater Chem Phys. 1995;39:209.

25. M. Elachouri M, Hajji MS, Salem M, et al. Corrosion. 1996;52:103.

26. Bouklah M, Hammouti B, Lagrenée M, et al. Corros Sci. 2006;48: 2831.

27. Popova A, Christov M, Raicheva S, et al. Corros Sci. 2004;46:1333.

28. Bockris JO'M, Young B. J Electrochem Soc. 1991;138:2237.

29. Touhami F, Aouniti A, Kertit S, et al. Corros Sci. 2000;42:929. 